\title{
Science Students' Spontaneous Utilization of School Library with Logistic Growth Model: A Focus on Gender
}

\author{
Chinedu Victor Obasi* \\ Department of Mathematics, Alvan Ikoku Federal College of Education, Owerri, Imo State, Nigeria \\ *Corresponding author: obasi1212@gmail.com
}

\section{ARTICLE HISTORY}

Received : 28 September 2020

Revised : 11 February 2021

Accepted : 16 April 2021

\section{KEYWORDS}

Library;

Spontaneous Utilization;

Gender;

Logistic Equation;

\begin{abstract}
In this paper the logistic growth model of spontaneous utilization of school library in Imo State, is presented. First-order variables separable logistic equation is solved. The parameters that gave the best logistic curve for the data were determined. The number of male and female science students who utilized school library spontaneously also is presented. The logistic equation allows rigorous estimation of $2.34 \%$ growth rate of male science students' spontaneous utilization of school library in Imo State. While that of female students is decreasing by $2.71 \%$. The results revealed that male students are experiencing upward trend in the spontaneous utilization of school library while their female counterparts are experiencing downward trend. Therefore, it is recommended that science students should utilize the school library resources spontaneously without being induced to do so. They should also develop passion for reading because reading books pushes readers to use their imaginations and encourages creativity for scientific endeavours.
\end{abstract}

\section{INTRODUCTION}

Library is one of those resources which are essential to support and strengthen the educational quality. School library information resources are seen as all inputs which are utilized in the library in order to provide good learning environment for students and teachers so as to be able to achieve educational goals. This variety of library information resources is essential to facilitate the school library fulfill its functions among which are: to thoroughly provide information resources necessary for the school's educational programmes and to help in improving and rising the reading skills and learning habits of students. Fakomogbon, et al in Obasi, Ibebuike and Ugochukwu (2017) argued that school library help to support the school curriculum by providing up-date information to keep teachers and students abreast of new development. The importance of Library cannot be over-emphasized. Unfortunately, library facilities are the most ignored area in educational institutions of teacher education.

Student expectations and demands of the library could be reflected in their library information resources usage. Salisu in Obasi et al (2017) argued that, the extent at which students and young people of today will be creative, informed and knowledgeable will be shaped by the usage of the library resources available within the school. This is to say that, the usefulness of any school library resource depends on its maximum utilization by students otherwise it is as good as wasted. That is why Fakomogbon, et al as cited in Obasi et al (2017) had stated that lack of standard school library with relevant information resources which students could use for their studies could be one of the major causes of mass failure in the school.

Several studies have been done on the use of school libraries (see Clabo, 2002; Daniel, 2004; Abdullahi, 2008; Agyekum \& Filson, 2012; Obasi et al, 2017). These studies revealed that most of the students use library resources and services to supplement their class notes, assignments and helped them in examination preparation etc. and have also shown that there is strong connection between the students' use of school library and their academic performance. Students that use the school library often perform better in test and examination than students who fail to use the school library. For students to strive for academic excellence, especially in mathematics, physics, chemistry, biology, etc. they should learn to utilize the school library spontaneously. Spontaneous utilization of school library in this context would mean students' use of school library intrinsically without being induced by their lecturers, classmates, assignment, examination, etc. Although, Obasi et al (2017) in earlier study apply logistic model to predict growth rate at which students utilize the school library among the undergraduate students. However, the present study will observe spontaneous utilization of school library which differs with the previous study. In this paper we examine male and female science students' spontaneous utilization of school library using logistic growth model. 


\section{Logistic Growth Model}

Let $P(t)$ be the number of science students who utilized school library spontaneously as a function of time. We consider the case of time rate of change of a population $P(t)$ with constant birth and death is $P^{\prime}(t)=k P$, where $k$ is the constant of proportionality and the solution is $P(t)=P\left(t_{0}\right) e^{k\left(t-t_{0}\right)}$. We note, Malthusian principle of population provides unlimited growth of a population according to exponential solution. However, for more realistic approach (logistic law) it reduces to the form:

$\frac{d P}{d t}=k P\left(1-\frac{P}{M}\right)=\alpha P-\beta P^{2}$, where $\alpha=k$ and $\beta=\frac{k}{M}$

where $k$ is the rate of growth, $M$ is the carrying capacity and the nonlinear term $\beta P^{2}$ can be interpreted as a kind of social friction. Equation (1) was presented by P.F. Verhulst in 1838 as population growth model. In this model, the relative growth rate decreases linearly from a value $k$ when the population is a negligible fraction of carrying capacity to 0 when the carrying capacity $M$ is reached.

\section{Solution of Logistic Growth Model}

The logistic equation is separable, and in separated form it appears as follows:

$\frac{1}{P(M-P)} d P=\frac{k}{M} d t$,

Integration by partial fractions yields

$\frac{1}{M} \int\left(\frac{1}{P}+\frac{1}{M-P}\right) d P=\frac{1}{M} \operatorname{In}\left(\frac{P}{M-P}\right)=\frac{k}{M} t+c$, where $c$ denotes the integration constant. Thus,

$$
\frac{P}{M-P}=e^{k t+M c}
$$

This equation can be solved for $P$ to obtain

$$
P(t)=\frac{M}{1+A e^{-k t}}
$$

Equation (3) is the solution of logistic equation (1).

Table 1. Number of science students who utilized school library spontaneously

\begin{tabular}{ccccccccc}
\hline$t$ & $P_{\text {male }}(t)$ & $P_{\text {female }}(t)$ & $t$ & $P_{\text {male }}(t)$ & $P_{\text {female }}(t)$ & $t$ & $P_{\text {male }}(t)$ & $P_{\text {female }}(t)$ \\
\hline 4 & 35 & 31 & 12 & 42 & 27 & 20 & 54 & 32 \\
\hline 5 & 37 & 27 & 13 & 42 & 29 & 21 & 57 & 30 \\
\hline 6 & 39 & 24 & 14 & 40 & 21 & 22 & 57 & 30 \\
\hline 7 & 41 & 30 & 15 & 46 & 23 & 23 & 59 & 24 \\
\hline 8 & 41 & 28 & 16 & 49 & 25 & 24 & 61 & 21 \\
\hline 9 & 43 & 22 & 17 & 51 & 21 & 25 & 64 & 20 \\
\hline 10 & 44 & 32 & 18 & 50 & 24 & 26 & 60 & 18 \\
\hline 11 & 45 & 38 & 19 & 54 & 22 & 27 & 65 & 15 \\
\hline
\end{tabular}

Source: Author's field observation, 2020.

\section{PLOT OF POPULATION DYNAMICS}

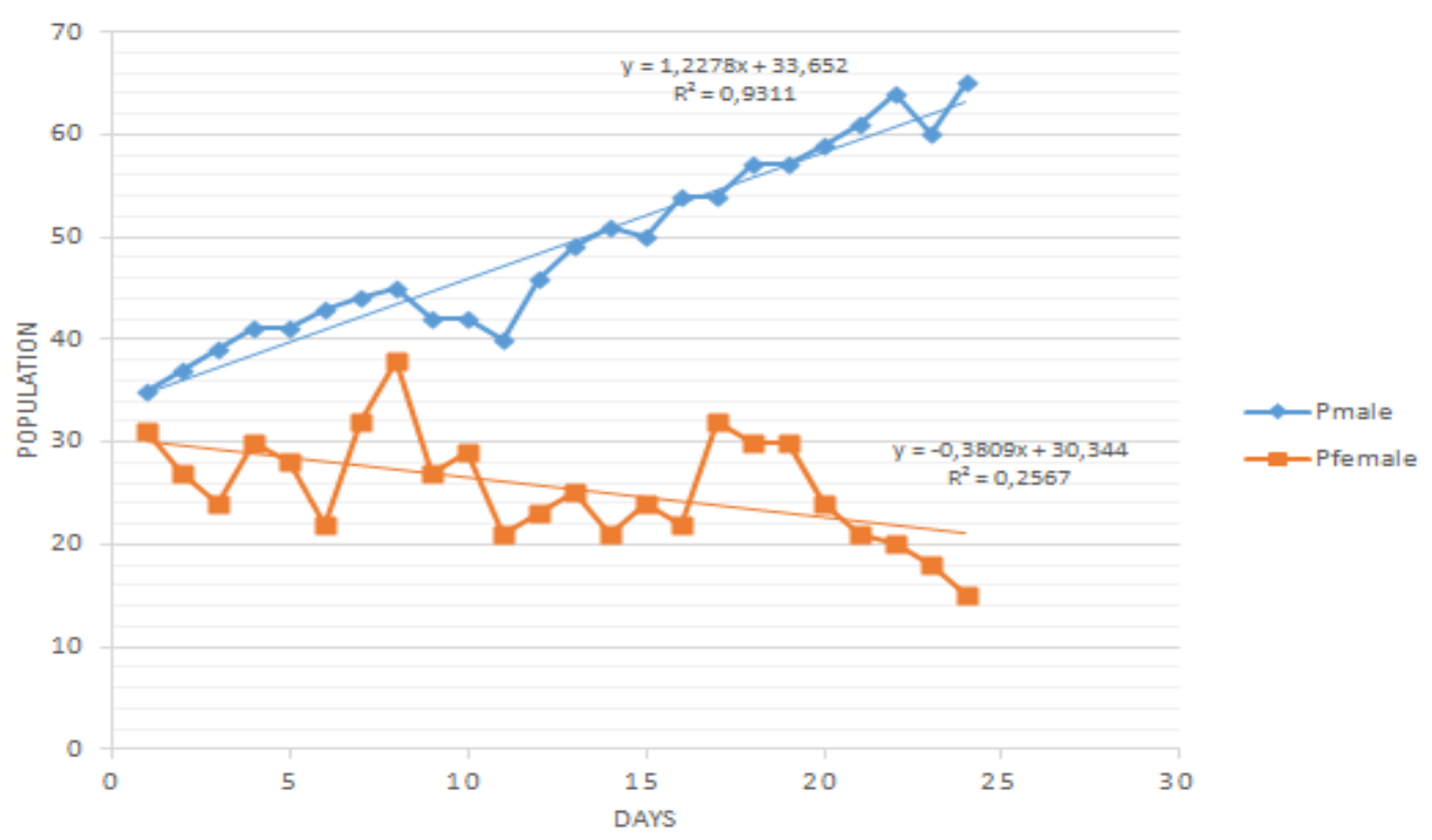

Figure 1. Plot of population dynamics on spontaneous utilization of school library 


\section{Fitting a Logistic Curve to Data}

In Table 1 we found that we could find a logistic curve passing through points in the plane. Here we try to find parameters that will give the best logistic curve for the data. The following method works well in cases where the logistic equation is an appropriate model for population growth, such as the spontaneous utilization of school library. Solutions of the logistic equation satisfying the conditions is given below.

$$
\begin{aligned}
& P_{\text {male }}(0)=35, P_{\text {female }}(0)=31, P_{\text {male }}(27)=65, P_{\text {female }}(27)=15 \text { and } M=2500 . \\
& P_{\text {male }}(t)=\frac{M}{1+A_{m} e^{-k_{m} t}} \Leftrightarrow 35=\frac{2500}{1+A_{m} e^{-k_{m}(0)}} \Rightarrow A_{m}=70.428 \\
& P_{\text {female }}(t)=\frac{M}{1+A_{f} e^{-k_{f} t}} \Leftrightarrow 31=\frac{2500}{1+A_{f} e^{-k_{f}(0)}} \Rightarrow A_{f}=79.645
\end{aligned}
$$

Similarly,

$$
\begin{aligned}
& P_{\text {male }}(t)=\frac{M}{1+A_{m} e^{-k_{m} t}} \Leftrightarrow 65=\frac{2500}{1+70.428 e^{-k_{m}(27)}} \Rightarrow e^{-27 k_{m}}=0.5319 \Rightarrow k_{m}=0.0234 \\
& P_{\text {female }}(t)=\frac{M}{1+A_{f} e^{-k_{f} t}} \Leftrightarrow 15=\frac{2500}{1+79.645 e^{-k_{f}(27)}} \Rightarrow e^{-27 k_{m}}=-2.0800 \Rightarrow k_{f}=-0.0271
\end{aligned}
$$

Thus, the rate of growth of male science students' spontaneous utilization of school library is $2.34 \%$ while that of female students is decreasing by $2.71 \%$. It means that as time progresses, there will be $2.34 \%$ increase in the male science students' spontaneous utilization of school library while that of their female counterparts is decreasing by $2.71 \%$. This gives gender disparity in the growth rate of spontaneous utilization of school library.

\section{Discussion}

From the logistic model equation, the parameters of the mode gave the best logistic curve for the data and allows rigorous estimation of $2.34 \%$ growth rate of male science students' spontaneous utilization of school library in Imo State. While that of female students is decreasing by $2.71 \%$. It means that as time progresses, there will be $2.34 \%$ increase in the male science students' spontaneous utilization of school library while that of their female counterparts is decreasing by $2.71 \%$. The result shows that male students are experiencing upward trend in the spontaneous utilization of school library while their female counterparts are experiencing downward trend. This could be the reason why male students are achieving higher in mathematical sciences than their female counterparts. This is due to the fact that there is strong connection between the students' use of school library and their academic performance (Agyekum \& Filson, 2012; Obasi et al, 2017). Students that use the school library often perform better in test and examination than students who fail to use the school library (Abdullahi, 2008; Obasi et al, 2017). One would belief that in terms of academic achievement, male and female students have equal footing. This assertion may not be the case due to growth rates in the spontaneous utilization of school library based on gender, as reported in this study. Hence, male students may be achieving higher than their female counterparts in the mathematical sciences due deficiency in library utilization on the side of the female students. Although, Obasi et al, (2017) in earlier study found that the predicted growth rate at which students utilize the school library is approximately decreased by $3.8 \%$ per year, showing evidence of library utilization deficiency and inconsistency among the students. The study concluded that study-habits of the students were bad and academic performance of the students was poor. This by implication goes to show that school library utilization deficiency has an adverse effect on the students' reading habit and academic achievement. This could prove the gender disparity in the spontaneous utilization of school library among science undergraduate students in Imo State. Therefore, it is recommended that science students should utilize the school library resources spontaneously without being induced to do so. They should also develop passion for reading because reading books pushes readers to use their imaginations and encourages creativity for scientific endeavours.

\section{CONCLUSION}

The results revealed that male students are experiencing upward trend in the spontaneous utilization of school library while their female counterparts are experiencing downward trend. Therefore, it is recommended that science students should utilize the school library resources spontaneously without being induced to do so. They should also develop passion for reading because reading books pushes readers to use their imaginations and encourages creativity for scientific endeavours.

\section{REFERENCES}

Abdulahi, A. (2008). The role of libraries in primary and secondary education in Nigeria. Teaching Education Today, 8 (1 \& 2), 21-26.

Agyekummr, B.A \& Filson, C.K (2012). The challenges of school libraries after the implementation of the new educational reforms in Ghana. Library Philosophy and Practice (e-journal). Paper 932. Accessed from http://digitalcommons.unl.edu

Clabo, C.A (2002). Study of the library use practices of high school students in three East Electronic Theses and Dissertations. Paper 635 accessed on 26/07/14 from http://dc.etsu.edu/etd/635.

Daniel, C.I (2004). Efforts/Activities at schools' level by principals, headmasters, PTA to support provision of library services in school the case of Abuja Federal Capital Territory. Nigerian School Library Journal 5(1).

Obasi, C., Ibebuike, E. \& Ugochukwu, K. (2017) Application of differential equations to library utilization deficiency among students: Implication for national development. Journal of Research in Science and Technology Education (JORSTED), Maiden Edition, 57-65. 